\title{
The Chilean Strawberry [Fragaria chiloensis (L.) Duch.]: Genetic Diversity and Structure
}

\author{
Basilio Carrasco ${ }^{1}$ \\ Instituto de Biología Vegetal y Biotecnología and Centro de Investigación en \\ Biotecnología Silvoagrícola (CIBS), Universidad de Talca, Avenida Lyrcay $S / N$, \\ 2 North 685, Casilla 747, Talca, Chile \\ Marcelo Garcés and Pamela Rojas \\ Instituto de Biología Vegetal y Biotecnología, Universidad de Talca, Talca, Chile \\ Guillermo Saud \\ Instituto de Biología Vegetal y Biotecnología and Centro de Investigación en \\ Biotecnología Silvoagrícola (CIBS), Universidad de Talca, Talca, Chile \\ Raúl Herrera \\ Instituto de Biología Vegetal y Biotecnología, Universidad de Talca, Talca, Chile
}

Jorge B. Retamales

Facultad de Ciencias Agrarias, Universidad de Talca and Centro de Investigación en Biotecnología Silvoagrícola (CIBS), Universidad de Talca, Talca, Chile

\section{Peter D.S. Caligari \\ Instituto de Biología Vegetal y Biotecnología, Universidad de Talca, Talca, Chile}

AdDITIONAL INDEX wORDs. wild strawberry, white strawberry, ISSR, Bayesian clustering, plant domestication

\begin{abstract}
The chilean strawberry displays high fruit quality and tolerance to abiotic and biotic factors. Additionally, this species has a rich cultural history going back for at least several thousand years in association with aboriginal people activities and continues at a reduced level today. After its introduction to Europe during the 18th century, it formed an interspecific hybrid to become the maternal species of the commercial strawberry, Fragaria $\times$ ananassa Duch. The objectives of the current investigation were to determine the level and patterns of partitioning of intersimple sequence repeat (ISSR) diversity. ISSR markers were used to assess the genetic diversity in 216 accessions of $\boldsymbol{F}$. chiloensis, which represented the two botanical forms present in Chile $[F$. chiloensis ssp. chiloensis $\mathrm{f}$. chiloensis and $\boldsymbol{F}$. chiloensis ssp. chiloensis f. patagonica (L.) Duch.]. Our results showed high genetic diversity at the species level [polymorphic ISSR loci $(P)=89.6 \%$, gene diversity $(h)=0.24 \pm 0.17$, Shannon's index $(S)=0.37 \pm 0.24]$ and a lower genetic diversity in $\mathrm{f}$. chiloensis than $\mathrm{f}$. patagonica. The analysis of molecular variance (AMOVA) showed a moderate genetic differentiation among accessions $\left(\phi_{s t}=14.9 \%\right)$. No geographic patterns for ISSR diversity were observed. AMOVA, structure, and discriminant analysis indicated that accessions tend to group by botanical form. The impact of domestication on the genetic structure of chilean strawberry and its application to breeding and conservation are discussed.
\end{abstract}

The chilean strawberry is a polyploid $(2 \mathrm{n}=8 \mathrm{X}=56)$ clonally reproducing species, which belongs to the Rosaceae family (Hancock et al., 1999). Its natural populations are distributed widely in Chile between lat. $34^{\circ} 55^{\prime} \mathrm{S}$ and $47^{\circ} 33^{\prime} \mathrm{S}$ (Lavín et al., 2000), through the Andes and the Coastal Mountains, but outside Chile, it is also found on the Pacific coast of North America and in Hawaii. Based on morphological character-

Received for publication 28 Feb. 2006. Accepted for publication 7 Apr. 2007 This article was funded by Centro de Investigación en Biotecnología Silvoagrícola (CIBS), the Universidad de Talca through the DPI Programa de Investigación "Frutilla Chilena Integral," Programa Bicentenario de Ciencia y Tecnología-CONICYT/Banco Mundial: Inserción de Investigadores Postdoctorales No. 10, and the FONDECYT project 1050987 entitled "Genetic and biochemical characterization of fruit quality in Fragaria chiloensis using fullsib families."

We acknowledge the invaluable inputs of Arturo Lavín and Marta Maureira of the Experimental Station of Cauquenes, National Institute of Agricultural Research (INIA), Chile in terms of plant material and information.

${ }^{1}$ Corresponding author. E-mail: bcarrasc@utalca.cl. istics, there are two botanical forms: f. patagonica (wild type) and f. chiloensis. The former has small plants that produce high numbers of stolons and small red fruit, whereas the other form generates less stolons and displays large white-pink fruit.

The $\mathrm{f}$. chiloensis form is especially interesting because the native people cultivated it before the Spaniards arrived to central Chile in 1542 (Darrow, 1966; Medina, 1952; Wilhelm and Sagen, 1972). Moreover, it is considered to be the mother of the commercial strawberry ( $F$. xananassa), which is now consumed on a worldwide basis (Darrow, 1966; Hancock, 1990; Hancock et al., 1999; Wilhelm and Sagen, 1972). Thus, $F$. chiloensis is a valuable source of genes for the genetic improvement of the commercial strawberry as well as having the potential to be "revived" as a new and exotic alternative fresh fruit in the world market.

Previous genetic analyses of $F$. chiloensis using molecular markers have been scarce and have had low statistical resolution; thus, they have not allowed the genetic structure of this species to be defined (Becerra et al., 2001; Hinrichsen et al., 
1999). To clarify the organization of its genetic diversity, it is necessary to use a highly polymorphic molecular marker system and apply powerful statistical methods. The intersimple sequence repeat (ISSR) polymerase chain reaction (PCR) is a cheap, fast, and simple technique that displays a reliable banding pattern with the capability of detecting high levels of variability among individuals. It has the advantage of a wide genomic distribution and high variability (Zietkiewicz et al., 1994). For these reasons, ISSRs have been used to analyze genetic diversity, individual genotyping, and genome mapping (Arnau et al., 2002; Gilbert et al., 1999; Herrera et al., 2002).

In the last few years, several sophisticated statistical methods have become available to study the genetic structure of populations (Dawson and Belkhir, 2001; Pritchard et al., 2000). One of these is the Bayesian clustering approach, which allows identification of subgroups, assigning individuals probabilistically to these groups with unknown structure (Pritchard et al., 2000).

The objectives of the current investigation were to determine the level and patterns of partitioning of ISSR diversity in F. chiloensis ssp. chiloensis, to clarify its genetic structure, and establish a baseline to assist conservation and breeding programs.

\section{Materials and Methods}

Plant material. A sample of 216 accessions of $F$. chiloensis was used in this study, which represented the natural area of distribution in Chile (Fig. 1) plus one reference accession from Ecuador [96AMB1A (Carrasco, 2006)]. It should be noted, however, that the two botanical forms f. patagonica and f. chiloensis are not equally represented in the sample; in fact, f. chiloensis is only present as 22 samples, whereas f. patagonica as 194 . The 22 represent both the total existing germplasm for this botanical form and the different areas where the species is cultivated. This means that we need to exercise caution when interpreting any differences between the two groups because f. chiloensis is represented by rather few accessions (indeed, in the full analysis, it is only possible to include 18 as having a full data set). Initially, 80 accessions were intensively studied with ISSR markers; later the sample was expanded with a further 136 accessions. Leaves were collected from each sampled plant and fast-frozen in liquid nitrogen. All samples were then stored at $20{ }^{\circ} \mathrm{C}$ until DNA extraction was performed. All plant material and details of their geographic origin were obtained from the Experimental Station of Cauquenes, National Institute of Agricultural Research, Chile. The identification and geographic origin of each of the 216 accessions are available at Carrasco (2006); however, it should also be noted that most of the accessions were collected in collaboration with colleagues from the United States and so are retained in the National Clonal Germplasm Repository at Corvallis, OR.

DNA EXTRACTION AND INTERSIMPLE SEQUENCE REPEAT ASSAY. DNA extraction and PCR conditions were carried out according to Herrera et al. (2002). In this study, a set of 26 primers (set ISSR 100/8, Biotechnology Laboratory from University of British Columbia, Vancouver) was tested. The basic characteristics of the primers that gave positive results are shown in Table 1. All PCR products were checked by electrophoresis on $2 \%$ agarose gel, run in TAE $1 \times$ buffer, and visualized by ultraviolet fluorescence after staining with ethidium bromide $\left(0.25 \mu \mathrm{L} \cdot \mathrm{mL}^{-1}\right.$ staining solution).

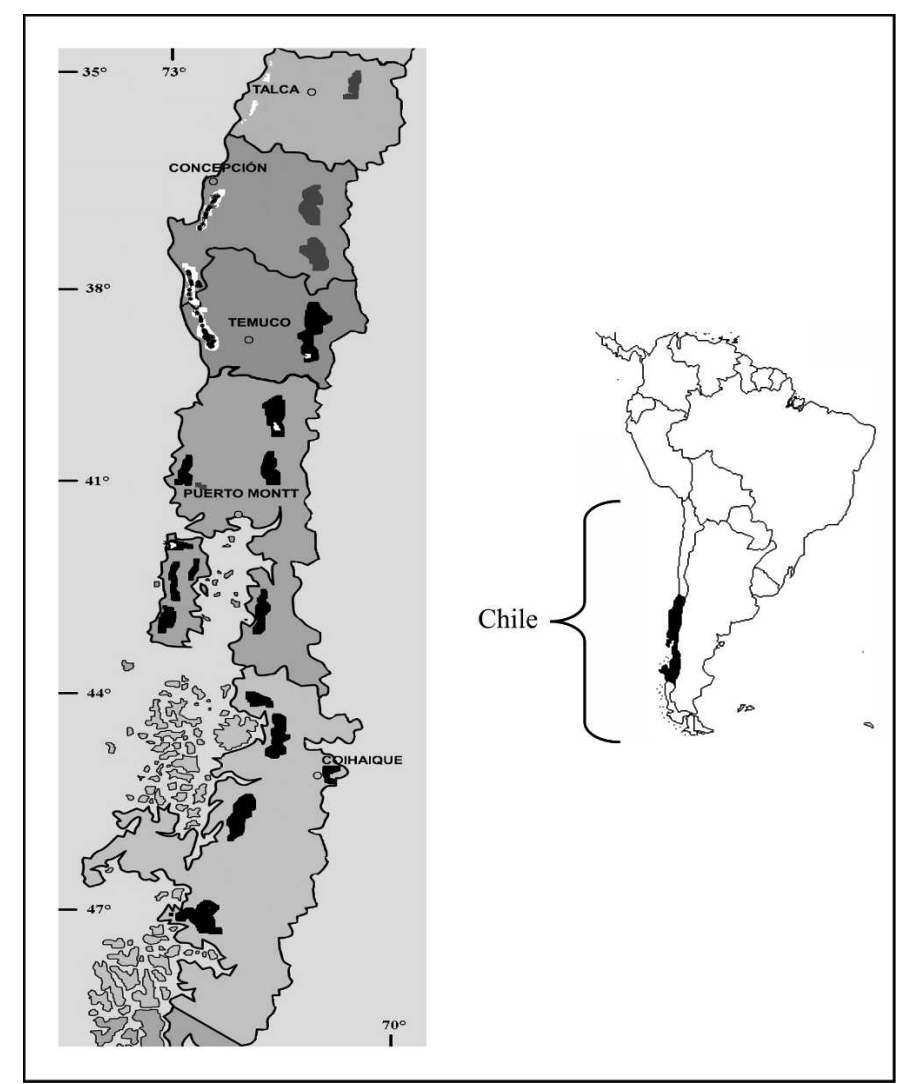

Fig. 1. Natural geographic distribution of the chilean strawberry. The black zone on the map the South America on the right-hand side indicates the natural distribution of $F$. chiloensis in Chile. The more detailed map, on the left, shows black and white zones indicating, respectively, the locations of $F$. chiloensis ssp. chiloensis f. patagonica and F. chiloensis ssp. chiloensis f. chiloensis.

INTERSIMPLE SEQUENCE REPEAT DATA ANALYSIS. From the ISSR patterns, each band was denoted as present (1) or absent (0) for each individual. Initially, 80 accessions were analyzed with 26 primers to select the more informative primers from this set. Selection of accessions was based on a representative sample of the geographical distribution of $F$. chiloensis samples. Finally, with a set of 216 accessions, only primers with complete and scorable banding patterns were studied to minimize error. For all statistical analyses, the accessions were grouped according to geographical origin (based on GPS positions) of their collection and by botanical form (f. chiloensis or f. patagonica). The POPGENE computer package (Yeh et al., 1997) was used to calculate for each population the percentage of polymorphic ISSR loci (\%P) and Nei's gene diversity (h) (Nei, 1973). The relative degree of phenotypic diversity was measured with Shannon's index $\left(\mathrm{S}=-\Sigma \mathrm{P}_{\mathrm{i}} \log \mathrm{P}_{\mathrm{i}}\right)$, in which $\mathrm{P}_{i}$ is the frequency of the presence of the amplified fragment (Shannon, 1948).

The hierarchical ISSR frequency distribution was analyzed using analysis of molecular variance [AMOVA (Excoffier et al., 1992)]. The statistical significance of variance components were evaluated using null distributions generated by random permutation of individuals $(100,000$ bootstrap permutations). Additionally, discriminant analysis was used to verify which were the most important bands associated with genetic differentiation among accessions. 
Table 1. Characteristics of six intersimple sequence repeat primers used for the analysis of Fragaria chiloensis accessions.

\begin{tabular}{|c|c|c|c|c|c|}
\hline Primer & $\begin{array}{l}\text { Sequence } \\
5^{\prime}-3^{\prime}\end{array}$ & $\begin{array}{c}\text { Total bands } \\
\text { (no.) }\end{array}$ & $\begin{array}{l}\text { Polymorphic } \\
\text { bands (no.) }\end{array}$ & $\begin{array}{l}\text { Band size range } \\
\text { (base pairs) }\end{array}$ & $\begin{array}{l}\text { Annealing } \\
\text { temp }\left({ }^{\circ} \mathrm{C}\right)\end{array}$ \\
\hline UBC811 & $(\mathrm{GA})_{8} \mathrm{C}$ & 13 & 12 & $400-1150$ & 52 \\
\hline UBC841 & $(\mathrm{GA})_{8} \mathrm{YC}$ & 11 & 10 & $450-1100$ & 54 \\
\hline UBC 847 & $(\mathrm{CA})_{8} \mathrm{RC}$ & 10 & 4 & $800-1500$ & 54 \\
\hline UBC 850 & $(\mathrm{GT})_{8} \mathrm{YC}$ & 12 & 7 & $450-1500$ & 54 \\
\hline UBC855 & $(\mathrm{AC})_{8} \mathrm{YT}$ & 12 & 6 & $300-1210$ & 52 \\
\hline
\end{tabular}

${ }^{\mathrm{z}}$ Sequence in degenerated primers, $\mathrm{R}$ can be either $\mathrm{A}$ or $\mathrm{G}$ nucleotide, whereas $\mathrm{Y}$ can be either $\mathrm{C}$ or $\mathrm{T}$ nucleotide.

YTotal bands consistently visualized from the agarose gel.

${ }^{x}$ At least one individual must show presence or absence of a band.

The spatial structure of $F$. chiloensis accessions was first analyzed by principle coordinate analysis (PCO) using NTSYS software (version 2.02i; Exeter Software, Setauket, NY). For binary molecular markers, like ISSR, pairwise genetic Jaccard distances were calculated according to Sneath and Sokal (1973).

The presence of genetic structure, not detected by standard analytic methodologies, was analyzed with "Structure" software developed by Pritchard et al. (2000). In this method, individuals are assigned probabilistically to populations following the ancestry model "No Admixture," in which each individual is assumed to originate in one of $\mathrm{K}$ populations. This model was chosen because it has been more successful in detecting structure and is recommended for dominant marker systems (Pritchard and Wen, 2003), like ISSR. The allele frequency model used was "allele frequency correlated," which is useful for closely related populations because it improves the assignment of each individual. Different $\mathrm{K}$ populations were assumed ( $\mathrm{K}=1$ to $\mathrm{K}=7$ ) to determine the prior and posterior probability of $\mathrm{K}$ and 100,000 iterations were run for both "burn-in" periods and Markov chain Monte Carlo. The ancestry $(\mathrm{Q})$ values were estimated, which correspond to the posterior probability of each individual belonging to an assumed population. Moreover, the memberships were calculated as the number of accessions with $\mathrm{Q}$ values greater than 0.5 with respect to the total number of accessions predefined by clustering.

\section{Results}

INTERSIMPLE SEQUENCE REPEAT PROFILES. Initially, 26 ISSR primers were used in this study; however, only primers with sequences $\mathrm{GA}, \mathrm{CT}, \mathrm{CA}, \mathrm{AC}$, or GT showed reliable band patterns (Table 1). Eleven primers whose sequences were AT and TA never amplified. The 216 accessions showed 73 scorable bands from six ISSR primers. Most polymorphism was present in fragments ranging from 300 to 800 base pairs (bp) and 1000 to $1500 \mathrm{bp}$. Because the two sample sizes showed similar genetic parameters, in the following sections, the results based only on 216 accessions are presented.

LEVEL OF GENETIC DIVERSITY. Without considering any previous classification (geographic origin or botanical form), the genetic parameters of $F$. chiloensis accessions were $P=$ $89.6 \%, \mathrm{~h}=0.24$, and $\mathrm{S}=0.37$.

As shown in Table 2A, it was possible to establish that f. chiloensis displayed half of the genetic diversity $(P=48 \%$, $\mathrm{h}=0.12, \mathrm{~S}=0.19)$ that $\mathrm{f}$. patagonica showed $(P=90 \%, \mathrm{~h}=$ $0.25, \mathrm{~S}=0.38$ ), which shows that despite the small sample size of f. chiloensis, the statistical differences are highly significant.

However, when geographic origin was considered (Table 2B), there was no obvious pattern in the variability when we analyzed the f. patagonica accessions (omitting the f. chiloensis accessions, which might complicate the interpretation because of their sparse distribution). For this analysis, we grouped f. patagonica accessions by latitude into about equal sizes to

Table 2. Summary of statistics for the genetic variation for 216 Fragaria chiloensis accessions using 73 intersimple sequence repeat bands: (A) accessions grouped by botanical form and (B) $194 \mathrm{~F}$. chiloensis ssp. chiloensis f. patagonica accession grouped by latitude. ${ }^{\mathrm{z}}$

\begin{tabular}{lcccc}
\hline & $\begin{array}{c}\text { Sample size } \\
\text { (no.) }\end{array}$ & $\begin{array}{c}\text { Polymorphic } \\
\text { loci }(\%)\end{array}$ & $\begin{array}{c}\text { Gene diversity } \\
( \pm \mathrm{SE})\end{array}$ & $\begin{array}{c}\text { Shannon's index } \\
( \pm \mathrm{SE})\end{array}$ \\
\hline $\begin{array}{l}\text { A. Botanical form } \\
\quad \text { Chiloensis form }\end{array}$ & 18 & 48 & $0.12 \pm 0.04$ & $0.19 \pm 0.05$ \\
$\quad \begin{array}{l}\text { Patagonica form } \\
\text { Average }\end{array}$ & 148 & 90 & $0.25 \pm 0.01$ & $0.38 \pm 0.02$ \\
B. Latitude (f. patagonica) & 69 & 0.19 & 0.29 & \\
$35^{\circ} \mathrm{S}$ to $36^{\circ} \mathrm{S}$ & 27 & 62 & $0.19 \pm 0.036$ & $0.29 \pm 0.051$ \\
$37^{\circ} \mathrm{S}$ to $38^{\circ} 50^{\prime} \mathrm{S}$ & 26 & 70 & $0.21 \pm 0.036$ & $0.32 \pm 0.052$ \\
$39^{\circ} 50^{\prime} \mathrm{S}$ to $41^{\circ} 40^{\prime} \mathrm{S}$ & 28 & 58 & $0.20 \pm 0.035$ & $0.30 \pm 0.050$ \\
$41^{\circ} 40^{\prime} \mathrm{S}$ to $43^{\circ} 30^{\prime} \mathrm{S}$ & 25 & 60 & $0.23 \pm 0.040$ & $0.34 \pm 0.057$ \\
$43^{\circ} 30^{\prime} \mathrm{S}$ to $45^{\circ} \mathrm{S}$ & 26 & 72 & $0.27 \pm 0.038$ & $0.41 \pm 0.052$ \\
$45^{\circ} \mathrm{S}$ to $50^{\circ} \mathrm{S}$ & 29 & 68 & $0.22 \pm 0.031$ & $0.35 \pm 0.042$ \\
& & & 0.22 & 0.34
\end{tabular}

${ }^{\mathrm{z}}$ Analyses automatically excluded samples without a full data set. The accession from Ecuador was omitted. 
avoid excessive sampling effects. The genetic diversity parameters ranged between $P=58 \%$ and $72 \%, \mathrm{~h}=0.20$ and 27 , and $\mathrm{S}=0.30$ and 0.4 . No significant differences were observed between geographical locations.

DISTRIBUTION OF INTERSIMPLE SEQUENCE REPEAT DIVERSITY AND GENETIC STRUCTURE. AMOVA revealed that most genetic variation was within groups or populations (Table 3). By geographical origin, $97.0 \%$ of ISSR variability was found within latitudes, and a low but significant proportion of genetic variance was attributable to differences among latitudes $(3.0 \%$, $P \leq 0.01$; Table 3A). AMOVA for the botanical form showed that a high proportion of the ISSR variability was distributed within the f. chiloensis and f. patagonica forms (85.1\%; Table $3 \mathrm{~B})$, although it was $12 \%$ less than within the geographical origin. The variance between $\mathrm{f}$. chiloensis and f. patagonica was $\approx 5$ times higher than among geographical origins $(14.9 \%, P \leq 0.01)$. The PCO analysis only explained $\approx 30 \%$ of the data variability and no apparent structure was observed (data not shown).

Of a total of 73 ISSR bands analyzed, only 11 bands with sequences GA, CT, and AC explained the differences between the two botanical forms (Table 4); all of them had significant levels of variance $(0.12$ to $0.49, P \leq 0.01)$ as determined by AMOVA. Similar results were found by discriminant analysis (Wilk's lambda $=0.186391, P \leq 0.01$; Mahalanobis distance $=$ 21.3464, $P \leq 0.01)$.

Bayesian analysis always tended to group $F$. chiloensis accessions in two clusters, which were in agreement with the botanical forms. These clusters showed constant alpha values and an asymmetric individual assignment of the accessions to each group. Interestingly, the previous classification of $F$. chiloensis, in two botanical forms, was able to predict the ancestry and memberships of each accession. So, the accessions previously defined as belonging to f. chiloensis and f. patagonica had on average an ancestry greater than 98\% and 97\%, respectively, and $98 \%$ of membership in both groups with only two accessions failing to fit in the preclassified groups.

\section{Discussion}

The chilean strawberry is a long-lived species, which in Chile displays a wide geographic distribution (lat. $35^{\circ} \mathrm{S}$ to $47^{\circ} \mathrm{S}$ ) but with populations also found on the Pacific coast of North America and in Hawaii. Its mode of reproduction is

Table 3. Analysis of molecular variance ${ }^{z}$ of 73 intersimple sequence repeat bands in Fragaria chiloensis accessions: (A) 194 accession F. chiloensis ssp. chiloensis f. patagonica grouped by latitude and (B) 216 accession grouped by botanical form $(F$. chiloensis ssp. chiloensis f. chiloensis and $F$. chiloensis ssp. chiloensis f. patagonica).

\begin{tabular}{lrrcc}
\hline & df & $\begin{array}{r}\text { Sum of } \\
\text { squares }\end{array}$ & $\begin{array}{c}\text { Variance } \\
\text { components }\end{array}$ & $\begin{array}{c}\text { Percentage } \\
\text { of variation }\end{array}$ \\
\hline $\begin{array}{l}\text { A. Latitude (f. patagonica) } \\
\quad \text { Among latitudes }\end{array}$ & 5 & 9.05 & 0.04 & $3.0^{*}$ \\
$\quad \begin{array}{l}\text { Within latitudes } \\
\text { B. Botanical form }\end{array}$ & 188 & 260.27 & 1.38 & 97.0 \\
f. chiloensis versus & & & \\
$\quad$ f. patagonica & 1 & 10.63 & 0.24 & $14.9^{*}$ \\
$\quad$ Within each group & 214 & 286.82 & 1.34 & 85.1 \\
\hline "Analysis was carried out using pairwise genetic distances. The \\
significance of $P$ value was estimated after 100,000 permutations. \\
$* P \leq 0.01$.
\end{tabular}

Table 4. Percentage variance for 11 intersimple sequence repeat primers involved in genetic differentiation among accessions of Fragaria chiloensis ssp. chiloensis f. patagonica and F. chiloensis ssp. chiloensis f. chiloensis.

\begin{tabular}{lcc}
\hline Locus & Primer sequence & Variance $(\%)^{z}$ \\
\hline UBC841-1100 & $(\mathrm{GA})_{8} \mathrm{YC}$ & 0.23 \\
UBC841-830 & $(\mathrm{GA})_{8} \mathrm{YC}$ & 0.34 \\
UBC841-700 & $(\mathrm{GA})_{8} \mathrm{YC}$ & 0.28 \\
UBC841-650 & $(\mathrm{GA})_{8} \mathrm{YC}$ & 0.26 \\
$\mathrm{UBC} 841-500$ & $(\mathrm{GA})_{8} \mathrm{YC}$ & 0.18 \\
UBC844-1500 & $(\mathrm{CT})_{8} \mathrm{RC}$ & 0.17 \\
UBC844-1490 & $(\mathrm{CT})_{8} \mathrm{RC}$ & 0.38 \\
UBC844-1100 & $(\mathrm{CT})_{8} \mathrm{RC}$ & 0.17 \\
UBC855-1031 & $(\mathrm{AC})_{8} \mathrm{YT}$ & 0.49 \\
UBC855-550 & $(\mathrm{AC})_{8} \mathrm{YT}$ & 0.25 \\
UBC855-380 & $(\mathrm{AC})_{8} \mathrm{YT}$ & 0.12
\end{tabular}

${ }^{\mathrm{z}}$ Significant at $P \leq 0.01$.

asexual (stolons) and sexual. It is an outcrossing species whose pollen is dispersed by wind and insects and its seeds by gravity and animals (Hancock, 1999). Unfortunately, there are only few reports of ISSR diversity in plants that share some of these biological attributes; one of them is Geum reptans L. (Rosaceae), which shows a gene diversity $[\mathrm{h}=0.22$ (Pluess and Stöcklin, 2004)] similar to the chilean strawberry $(\mathrm{h}=0.23$ to 0.24). In contrast, the clonally cultivated pawpaw [Asimina triloba (L.) Dunal] showed $\mathrm{h}=0.36$ (Pomper et al., 2003), which is higher than that found in this investigation.

Nybom (2004) indicated that estimates of genetic diversity in plants using randomly amplified polymorphic DNA (RAPD), amplified fragment length polymorphism (AFLP), and ISSR might be directly comparable. This author compiled 281 studies of genetic variability based on those dominant molecular markers that showed an average gene diversity ranging between $\mathrm{h}=0.24$ and 0.27 . On average, $F$. chiloensis displayed similar gene diversity with $\mathrm{h}=0.23$ to 0.24 at the species level. Previous genetic studies on $F$. chiloensis from Chile reported lower genetic diversity for AFLP markers with just 29\% of AFLP polymorphisms in 61 accessions (Becerra et al., 2001). The increased sample size, number of bands analyzed, and the high variability of the ISSR markers (Wolfe et al., 1998) in our study could reasonably explain the difference.

There was little evidence of any pattern in the geographical distribution of the ISSR diversity, although there was a hint of a lower level of variability at the extreme latitudes, particularly in the North. These results do coincide with the demographic structure of the chilean strawberry (Lavín et al., 2000). Between lat. $36^{\circ}$ and $43^{\circ} 30^{\prime} \mathrm{S}$, natural populations are distributed abundantly through Coastal and Andes Mountains (Lavín et al., 2000); however, in more southern or northern locations, the population size is reduced. In the northern part $\left(35^{\circ}\right.$ to $\left.36^{\circ} \mathrm{S}\right)$, the chilean strawberry is mostly the chiloensis form, which is cultivated in some small farms located in the Coastal Mountains, whereas a few wild f. patagonica populations grow naturally in reduced areas in the Andes Mountains. In extreme southern locations $\left(43^{\circ} 30^{\prime}\right.$ to $\left.50^{\circ} \mathrm{S}\right)$, only wild f. patagonica are found, which are spread through a thin strip of land with maritime influences.

Regardless of the geographic origin and botanical form of the chilean strawberry accessions, a significantly high proportion of ISSR diversity was found within accessions as 
revealed by AMOVA. This result is coincident with most plant species analyzed with different genetic marker systems such as allozymes, RAPD, AFLP, ISSR, and simple sequence repeat (Nybom, 2004). These levels of variability within groups can be explained by the propagation strategies in $F$. chiloensis. In this species, sexual reproduction is important for retaining genetic variability. Alpert et al. (1993) noted that, contrary to their predictions, natural populations of $F$. chiloensis from the California coast are composed of diverse genotypes that probably were established by dispersion of multiple seeds.

Genetic differentiation was significant (3.0\% to $14.9 \%)$ but lower than the average obtained from several plant species using dominant molecular markers such as RAPD, AFLP, and ISSR $\left(\phi_{\text {st }}=34 \%\right.$ to $35 \%$; Nybom, 2004). No geographical tendencies for ISSR diversity were detected in this study by dendrograms and PCO analysis carried out both on combined data and on data for the two botanical forms separately (data not shown). The genetic differentiation was supported by presence or absence of 11 ISSR bands, which were produced by dinucleotide primers GA, AC, and CT. This type of microsatellite sequence has been designated as some of the most abundant in Fragaria virginiana Mill. (Ashley et al., 2003) and in other plant genomes (Morgante et al., 2002). In the future, it will be interesting to characterize these differential ISSR bands because GA, CA, and CT microsatellites have been associated with transcribed regions of plant genomes (Kantety et al., 2002; Li et al., 2002, 2004; Morgante et al., 2002).

As AMOVA and discriminant analysis showed, the best picture of the organization of ISSR patterns in F. chiloensis was associated strongly with the botanical form. The "Structure" analysis was in agreement with these results. The best estimates of ancestry (greater than 98\%) and membership (97\% to 98\%) always were obtained when the accessions were grouped by their botanical form.

Based on the history of the chilean strawberry (Darrow, 1966), we suggest that almost certainly the origin of the whitefruited form (f. chiloensis) is narrow. Although the wild-form f. patagonica (red-fruited) is still collected during spring from the forest, most $\mathrm{f}$. chiloensis have been maintained under low input cultivation for a long time. It is believed that the aboriginal people of Chile (Mapuche and Picunche) cultivated f. chiloensis for more than 1000 years in coastal areas between latitudes $35^{\circ} \mathrm{S}$ and $39^{\circ} \mathrm{S}$ (Hancock et al., 1999; Lavín et al., 2000; Medina, 1917, 1952). The chiloensis form has a series of valuable traits such as erect habit, large size, and aromatic fruit, which were characters likely to have been favored by the Mapuche and Picunche people. So, it would be reasonable to assume that these people would select and maintain the best f. chiloensis phenotypes for cultivation, which of course would have influenced the genetic differences observed between f. chiloensis and f. patagonica.

Domestication activities have been noted as the most important factor to explain reduced genetic diversity and marked genetic differentiation observed between crops and their wild relatives. Examples making this point are abundant in the literature [Helianthus annuus L. (Burke et al., 2002); Zea mays L. (Doebley et al., 1997); Lycopersicum esculentum Mill. (Frary et al., 2000; Liu et al., 2002; van der Knaap and Tanksley, 2003); Oryza sativa L. (Yano et al., 2000)]. Although undoubtedly, human activities have played an important role in the genetic structure of $F$. chiloensis, other evolutionary forces cannot be dismissed.
CONSERVATION AND BREEDing CONSIDERATIONS. Recommendations for conservation and breeding based solely on molecular markers should be made with caution until the quantitative diversity can be evaluated intensively. However, some general considerations can be outlined for the appropriate use of genetic diversity to build an efficient core germplasm collection and also to choose parental lines that would avoid the effect of inbreeding depression as has been suggested for Fragaria L. species (Shaw, 1995, 1997). The two botanical forms (f. chiloensis and f. patagonica) showed genetic and morphological differences (Barrera, 2001; Lavín and Maureira, 2000). Although the chiloensis form showed lower ISSR diversity, it will be difficult to improve this situation, because all accessions available are currently present in the bank. Of the total number of accessions in the bank (300), only 22 accessions are f. chiloensis.

The high levels of ISSR diversity found on average in this study, together with the high variability for some morphological and physiological traits as reported in previous studies (Becerra et al., 2001; Hancock et al., 1999, 2003; Lavín and Maureira, 2000), suggest that the genetic base of $F$. chiloensis has enough variability to initiate a breeding program in its own right. It could also be an important source of useful alleles for other Fragaria species such as the commercial hybrid ( $F$. ×ananassa). In the future, it would be interesting to expand these analyses including accessions from other geographic areas such as the United States and Hawaii to strengthen the analyses of the pattern of variation present.

\section{Literature Cited}

Alpert, P., R. Lumaret, and F. Di Giusto. 1993. Population structure inferred from allozyme analysis in the clonal herb Fragaria chiloensis (Rosaceae). Amer. J. Bot. 80:1002-1006.

Arnau, G., J. Lallemand, and M. Bourgoing. 2002. Fast and reliable strawberry cultivar identification using inter simple sequence repeat (ISSR) amplification. Euphytica 129:69-79.

Ashley, M.V., J.A. Wilk, S.M.N. Styan, K.J. Craft, K.L. Jones, K.A. Feldheim, K.S. Lewers, and T.L. Ashman. 2003. High variability and disomic segregation of microsatellites in the octoploid Fragaria virginiana Mill. (Rosaceae). Theor. Appl. Genet. 107:1201-1207.

Barrera, C. 2001. Caracterización morfológica y fenológica de 52 accesiones de Fragaria chiloensis (L.) Duch. Tesis Ingeniero Agrónomo, Universidad de Talca, Chile.

Becerra, V., M. Paredes, A. Romero, and A. Lavín. 2001. Diversidad bioquímica y molecular en frutillas chilenas Fragaria chiloensis (L.) Duch. y su implicancia en el mejoramiento genético de la especie. Agricultura Técnica (Chile) 61:413-428.

Burke, J.M., S. Tang, S.J. Knapp, and L.H. Rieseberg. 2002. Genetic analysis of sunflower domestication. Genetics 161:1257-1267.

Carrasco, B. 2006. Identification and geographic location of chilean strawberry accessions. 22 Sept. 2006. <http://biologia.utalca.cl/ imagenes/supplementary-information-JASHS-00820.doc $>$.

Darrow, G.M. 1966. The strawberry: History, breeding and physiology. Holt, Rinehart and Winston, New York.

Dawson, K.J. and K. Belkhir. 2001. A Bayesian approach to the identification of panmictic populations and the assignment of individuals. Genet. Res. 78:59-77.

Doebley, J., A. Stec, and L. Hubbard. 1997. The evolution of apical dominance in maize. Nature 386:485-488.

Excoffier, L., P.E. Smouse, and J.M. Quattro. 1992. Analysis of molecular variance inferred from metric distances among DNA haplotypes: Application to human mitochondrial DNA restriction data. Genetics 131:479-491. 
Frary, A., T.C. Nesbitt, S. Grandillo, E. van der Knaap, B. Cong, J. Liu, J. Meller, R. Elber, K.B. Alpert, and S.D. Tanksley. 2000. fw2.2: A quantitative trait locus key to the evolution of tomato fruit size. Science 289:85-88.

Gilbert, J.E., R.V. Lewis, M.J. Wilkinson, and P.D.S. Caligari. 1999. Developing an appropriate strategy to assess genetic variability in plant germplasm collections. Theor. Appl. Genet. 98:11251131.

Hancock, J.F. 1990. Ecological genetics of natural strawberry species. HortScience 25:869-871.

Hancock, J.F. 1999. Strawberries. CAB International, Wallingford, UK. Hancock, J.F., P.W. Callow, S. Serce, and P.Q. Son. 2003. Variation in the horticultural characteristics of native Fragaria virginiana and Fragaria chiloensis from North and South America. J. Amer. Soc. Hort. Sci. 128:201-208.

Hancock, J.F., A. Lavín, and J.B. Retamales. 1999. Our southern strawberry heritage: Fragaria chiloensis of Chile. HortScience 34:814-816.

Herrera, R., V. Cares, M.J. Wilkinson, and P.D.S. Caligari. 2002. Characterization of genetic variation between Vitis vinifera cultivars from central Chile using RAPD and inter simple sequence repeat markers. Euphytica 124:139-145.

Hinrichsen, P., J. Kuncar, H. Masashi, C. Muñoz, and A. Lavín. 1999. Diversidad genética en accesiones chilenas de Fragaria chiloensis (L.) Duch., determinada mediante RADPs (random amplified polymorphic DNA). Agricultura Técnica (Chile) 59:151-168.

Kantety, R.V., M. La Rota, D.E. Matthews, and M.E. Sorrells. 2002. Data mining for simple sequence repeats in expressed sequence tags from barley, maize, rice, sorghum and wheat. Plant Mol. Biol. 48:501-510.

Lavín, A. and M. Maureira. 2000. La frutilla de fruto blanco. Boletín Instituto de Investigaciones Agropecuarias-Chile, No. 39.

Lavín, A., A. del Pozo, and M. Maureira. 2000. Distribución actual de Fragaria chiloensis en Chile. Plant Genet. Res. News 122:24-28.

Li, Y.-C., A.B. Korol, T. Fahima, A. Beiles, and E. Nevo. 2002. Microsatellites: Genomic distribution, putative functions and mutational mechanisms: A review. Mol. Ecol. 11:2453-2465.

Li, Y.C., A.B. Korol, T. Fahima, and E. Nevo. 2004. Microsatellites within genes: Structure, function, and evolution. Mol. Biol. Evol. 21:991-1007.

Liu, J., J. van Eck, B. Cong, and S.D. Tanksley. 2002. A new class of regulatory genes underlying the cause of pear-shape tomato fruit. Proc. Natl. Acad. Sci. USA 99:13302-13306.

Medina, J.T. 1917. Voces chilenas de los reinos animal y vegetal que pudieran incluirse en el diccionario de la lengua castellana. Imprenta Universitaria, Santiago, Chile.

Medina, J.T. 1952. Los aborígenes de Chile Fondo histórico y bibliográfico José Toribio Medina, Santiago, Chile.

Morgante, M., M. Hanafey, and W. Powell. 2002. Microsatellites are preferentially associated with non-repetitive DNA in plant genomes. Nat. Genet. 30:194-200.
Nei, M. 1973. Analysis of gene diversity in subdivided populations. Proc. Natl. Acad. Sci. USA 70:3321-3323.

Nybom, H. 2004. Comparison of different nuclear DNA markers for estimating intraspecific genetic diversity in plant. Mol. Ecol. 13:1143-1155.

Pluess, A.R. and J. Stöcklin. 2004. Population genetic diversity of the clonal plant Geum reptans (Rosaceae) in the Swiss Alps. Amer. J. Bot. 91:2013-2023.

Pomper, K.W., S.B. Crabtree, S.P. Brown, S.C. Jones, T.M. Bonney, and D.R. Layne. 2003. Assessment of genetic diversity of pawpaw (Asimina triloba) cultivars with intersimple sequence repeat markers. J. Amer. Soc. Hort. Sci. 128:521-525.

Pritchard, J.K., M. Stephens, and P. Donnelly. 2000. Inference of population structure using multilocus genotype data. Genetics 155:945-959.

Pritchard, J.K. and W. Wen. 2003. Documentation for structure software: Version 2.1. 26 July 2006. <http://pritch.bsd.uchicago. edu>.

Shannon, C. 1948. A mathematical theory of communication. Bell System Tech. J. 27:379-423.

Shaw, D.V. 1995. Comparison of ancestral and current-generation inbreeding in an experimental strawberry breeding population. Theor. Appl. Genet. 90:237-241.

Shaw, D.V. 1997. Trait mean depression for second-generation inbred strawberry populations with and without parent selection. Theor. Appl. Genet. 95:261-264.

Sneath, P.H.A. and R.R. Sokal. 1973. Numerical taxonomy-The principles and practice of numerical classification. Freeman, San Francisco.

Van der Knaap, E. and S.D. Tanksley. 2003. The making of a bell pepper-shaped tomato fruit: Identification of loci controlling fruit morphology in Yellow Stuffer tomato. Theor. Appl. Genet. 107:139-147. Wilhelm, S. and J.E. Sagen. 1972. A history of the strawberry: From ancient gardens to modern markets. Agriculture Publ., Univ. of California, Berkeley.

Wolfe, A.D., Q.-Y. Xiang, and S.R. Kephart. 1998. Assessing hybridization in natural populations of penstemon (Scrophulariaceae) using hypervariable inter simple sequence repeat (ISSR) bands. Mol. Ecol. 7:1107-1125.

Yano, M., Y. Katayose, M. Ashikari, U. Yamanouchi, L. Monna, T. Fuse, T. Baba, K. Yamamoto, Y. Umehara, Y. Nagamura, and T. Sasaki. 2000. Hd1, A major photoperiod sensitivity QTL in rice, is closely related to the Arabidopsis flowering time gene CONSTANS. Plant Cell 12:2473-2483.

Yeh, F.C., R.C. Yang, T.B.J. Boyle, Z.H. Ye, and J.X. Mao. 1997. POPGENE, the user-friendly shareware for population genetic analysis. Molecular Biology and Biotechnology Centre, University of Alberta, Edmonton, Canada.

Zietkiewicz, E., A. Rafalski, and D. Labuda. 1994. Genome fingerprinting by simple sequence repeat (SSR)-anchored polymerase chain reaction amplification. Genomics 20:176-183. 